\title{
Assessing Efficiency of Service Quality on Consumers Retention in Nigerian Mobile Service Industry
}

\author{
Bashir Danlami Sarkindaji
}

Othman Yeop Abdullah Graduate School of Business, Universiti Utara Malaysia, 06010 Sintok, Kedah, Malaysia

Noor Azmi Bin Hashim

Othman Yeop Abdullah Graduate School of Business, Universiti Utara Malaysia, 06010 Sintok, Kedah, Malaysia.

\section{Aliyu Olayemi Abdullateef}

Faculty of Business and Design, Swinburne University of Technology Sarawak Campus, Malaysia

bashirsdaji77@yahoo.com

\section{Doi:10.5901/mjss.2015.v6n1p195}

\section{Abstract}

This study examines the influence of service quality on retention through a mediating effect of customer satisfaction in the Nigerian mobile services industry. Based on a survey of 203 undergraduate students, questionnaires administered were analysed using SPSS statistical software to test the stated hypotheses. Findings revealed that innovativeness, technological competence and customer responsiveness have significant positive effect on customer retention. However, innovation was found to have more effect on satisfaction. Results also revealed that the effect of service quality dimensions on students' retention of mobile services is partially mediated by their satisfaction. This study recommended that organizations should design and implement appropriate service quality strategies capable of satisfying changing customers' needs and preferences.

Keywords: Service Quality, Customer Satisfaction, Retention, Responsiveness, Mediator

\section{Introduction}

Over the years, mobile services industry has witnessed a tremendous growth in the rate at which customers move in and out of networks. This has spawned a serious threat to survival of operators. According to Peng et al. (2013) "as the landscape for the mobile phone industry becomes increasingly competitive, mobile operators have escalated their efforts to retain existing customers and to compete for new customers". Hence, to be successful delivering standard services and superior satisfaction has become strategically necessary for operators. Previous studies have established that the cost of retaining existing customers is much lesser than for acquiring new customers (Coussement et al. 2010; Rust \& Zahorik, 1993).

In Nigeria, the increasing rate of customer churn in the mobile services sector has led to a problem of declining growth in the industry's subscriber base making it extremely difficult to attract new subscribers and retain the acquired ones (Adeleke \& Aminu, 2012; Omotayo \& Joachim, 2008). As customers drop out of networks on periodic basis, the expectations of service providers in terms of market share and profitability fluctuates drastically. Therefore, determining how to enhance customer retention and customer value becomes a key factor for sustainable growth of mobile service operators (Glady et al., 2009; Seo et al., 2008; Ahn et al., 2006).

One of the ways through which mobile service firms can achieve their customer retention goals is by designing and implementing appropriate SERVQUAL strategy. Efficient service quality strategy results from identifying and executing the necessary measures of service quality. Although previous studies in the mobile services sector specifically, has shown that service quality impacts customer satisfaction and retention through both economic and emotional factors (Lim et al., 2006). The intensity of implementation and measures used varies with organizations.

In view of the prevailing evidences conceptualization of measurement items for service quality are widely accepted. The contention is that service quality measurements in the mobile services sector is becoming an issue due to steep competition and increased market created by the rapidly changing consumer demands and expectations. Customers are becoming more complicated, segmented and demanding, and expect more in terms of customization, newness, quality 
and price (Stark, 2011). Although a good number of researches that have investigated service quality in the mobile services industry has confirmed their measurements valid (Malhotra \& Malhotra, 2013; Jonhson \& Sirikit, 2002). Yet, very few have investigated service quality measurements in relation to retention within the context of organizational innovativeness, technological competence and customer responsiveness and specifically within the context of Nigeria's mobile service sector.

This study is aimed at developing a conceptual model that seeks to assess the efficiency of service quality implementation on consumers' retention in the Nigeria's mobile services sector. The model integrates three dimensions of service quality to ascertain the association between students' satisfaction and retention of mobile services.

\section{Literature Review}

\subsection{What Comprises SERVQUAL?}

Studies on service quality have continually received considerable attention amongst distinct marketing scholars and practitioners in both past and recent times and incited by the unprecedented works of Parasuraman et al. (1985). Service quality can be defined as a consumer's evaluation of how well a given product or service measure up with desired and perceived satisfaction. Numerous studies have investigated service quality in diverse sectors ranging from retail (Omar, 2011), call centres (Jaiswal, 2008), internet (Gera, 2011), banking (Caruana \& Malta, 2002) and telecommunications (Malhotra \& Malhotra, 2013; Santouridis \& Trivellas, 2010; Johnson \& Sirikit, 2002). Although service quality in the global marketing atmosphere has been widely recognized and adopted, there exists controversy as to what constitutes service quality as well as assessing the efficiency of service quality in organizations?

Within the context of service quality literature, countless frameworks have been offered and developed for effective implementation and assessment of service quality strategies. For example, Parasuraman et al. (1988) explained service quality as "the overall evaluation of a specific service firm that results from comparing that firm's performance with the customers' general expectations of how firms in that industry should perform", and is characterized by five dimensions namely reliability, responsiveness, assurance, empathy, and tangibility. It is a measure of how well an organization's delivered services complements consumer's expectations (Santos, 2003).

Santouridis and Trivellas (2010) investigate the impact of service quality on satisfaction and loyalty in Greece, and proposed an integrated framework comprising of five dimensions namely value added services, mobile devices, customer service, pricing structure, and billing system. They found that when mobile companies care for effective service, appropriate pricing and billing structure they tend to have greater significant positive effect on customer satisfaction, which in turn has a strong positive influence on loyalty. Customer satisfaction plays a mediating role between service quality and customer loyalty (Caruana \& Malta, 2002; Santouridis \& Trivellas, 2010). Within the same mobile telephone sector Choi et al. (2007) conceptualised service quality using comparable measurement dimensions classified into network coverage, mobile device, value-added services, billing system, convenience and price structure in an attempt to portray an integrated view of a consumer.

\subsection{Innovation}

In today's business environment innovation is no doubt a key determinant as to why customers must be seen to remain with their service providers, and especially in the fiercely competing mobile telecommunication sector. According to OECD manual (2005) innovation is defined as "a product, process, marketing method or organizational method that is new (or significantly improved) to the firm, including products, processes and methods that firms are the first to develop and those that have been adopted from other firms or organizations". Innovation increases customer satisfaction as it maximizes the value of their purchases (Simon \& Yaya, 2012). In a study of US mobile service customers Malhotra and Malhotra (2013) found that the degree to which organizational customers observe their service providers to be innovative tend to have significant positive influence on their satisfaction and retention capability. They, however, argued that customers' perception of being innovative is proportionately as significant as their perception of the service quality delivered by the service provider. Similarly, low service quality perceptions results in high switching and low retention behaviours (Shin \& Kim, 2008) in both developed and developing economies (Rahman \& Azhar, 2011). Advancements in terms of both infrastructures, hardware and software capabilities have tremendous effect on satisfaction, retention, visa vies profitability and growth of mobile service sector.

Carton (2011) reported that insufficient competitive placement as an innovator in the mobile service sector has been affirmed to be instrumental to low customers' retention tendency. The relationship between customers' assessment 
of service quality and innovativeness of mobile service provider is compelling demand for supplementary services. The greater the innovativeness a service provider as perceived by customers, the more likely customers are willing and ready to be retained and invariably utilise surplus services (Malhotra \& Malhotra, 2013). For instance, Hamblen (2010) reported that the American Customer Satisfaction Index (ACSI) disclosed an increase in customer satisfaction resulting from invention of wireless services that combines limitless e-mail, text, as well as internet for $\$ 25$ monthly.

Delivering quality products or services as well as responding more efficiently to customers' needs and preferences requires organizations focusing more on innovation. Customers' needs and preferences are continually changing resulting in customized products or services offerings and that for firms to adapt to the global market and to provide customized solutions to consumers' innovation merits a special attention (Simon \& Yaya, 2012). Innovative products or services ensure that consumers' demands, needs as well as requirements are fulfilled (Simon \& Yaya, 2012).

\subsection{Technology Competence}

Having reliable technological capability is a prerequisite for firms' in the telecommunications industry to survive. In a survey of Spanish mobile shoppers Martin \& Catalán (2013) emphasised that mobile phone user tendency to make use of new technologies could encourage impulsiveness that might lead to dissatisfaction. They however, argued that customers' might develop keen interest into a service provider's products or services due to a firm's technological reliability. Weak technological reliability of a firm in the mobile service sector has been affirmed to be instrumental to low customers' retention tendency (Carton, 2011). Organizations in order to meet up with their changing consumer needs and preferences must be seen to commit greater portion of their resources to acquire the necessary technologies in place. Stark (2011) argued that offering high quality and customized products or services that are inventive as well as environmentally friendly to satisfying the demands and expectations of customers' require that organizations obtained the needed technology competencies.

It should, however, be noted that is one thing for a firm to be innovative and another for that firm to acquire the necessary technological competencies to produce and offer innovative products or services to their respective consumers. Malhotra and Malhotra (2013) stressed that service providers in the mobile services industry have established opportunities to link up with hardware as well as software suppliers to produce mechanisms that offer fascinating data competencies that are fast and reliable to customers.

\subsection{Customer Responsiveness}

The link between innovation and technological competency and their prospect of increased customer retention in organizations' is widely recognized in the literature. In particular what has been less widely implicit is the role that customer-organization relationships play in safeguarding successful relationship outcomes for both the organization and customer (Clark, 1997). To be responsive service providers must appreciate and proffer immediate solutions to their customer services encountered problems. Using 10 dimensions in an internet banking context, Jun and Cai (2001) investigated the key determinants of service quality. They found that customer reliability, responsiveness, access and accuracy were the most oftently considered source of customer satisfaction or dissatisfaction. In spite of the service sector under study, customer responsiveness was the second most significant dimension amongst the determinants of service quality (Parasuraman et al., 1988). Generally mobile operators have continually enhanced their mechanism competencies in the areas of speed, photo quality, video capture and face-to-face calls, etcetera in order to meet up their customer responsiveness targets (Malhotra \& Malhotra, 2013).

\subsection{Customer Satisfaction}

Satisfaction as used in the field of marketing is subjective based on individual customer perception or expectation. According to Kotler (2003) satisfaction "is a person's feeling of pleasure or disappointment resulting from comparing a product's perceived performance/ outcome in relation to his or her expectations". The wider the gap is between consumers' expectations and the real performance of the product or service, the higher is the consumer's dissatisfaction (Hutcheson \& Moutinho, 1998). Customer satisfaction is a key driver of customer retention and that a satisfied customer from the usage of a given product or service is always willing and ready to repeat his purchase of that same product or service that maximises his value.

Santouridis and Trivellas (2010) established that satisfaction resulting from effective service quality has strong positive effect on customer loyalty/retention of telecommunication services. Customers have higher tendency to retention 
and oppose to other options were they feel satisfied with organizational products or services (Fonnell, 1992; Anderson \& Sullivan, 1993). Similar studies in the context of mobile services have established also satisfaction as a strong forecaster of retention (Gerpott et al., 2001; Kim et al., 2004). Customer satisfaction possibly results to purchases repetition and favourable word-of-mouth publicity (Poon \& Low, 2005).

\subsection{Conceptual Model and Hypotheses}

In order to better comprehend how the predictor variables will interact to influence the criterion variable; a conceptual framework of the research is proposed as follows:

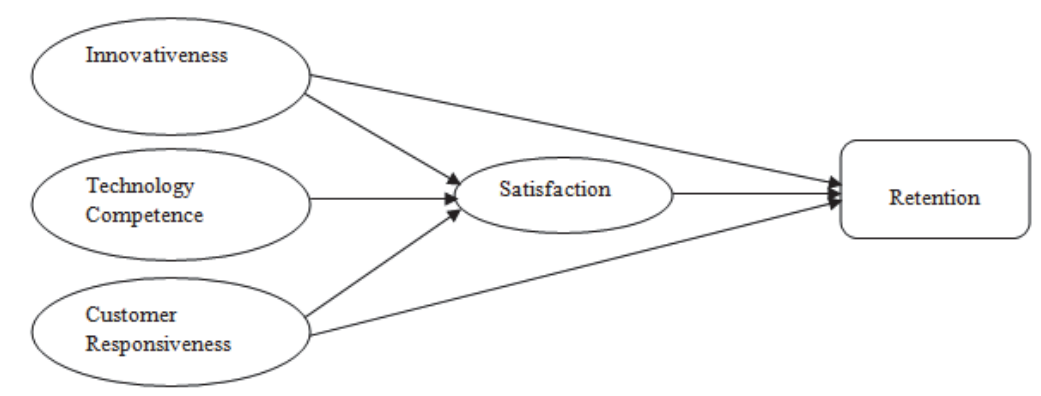

Figure 1. Research framework

The framework was developed based on the fact that effective quality services in terms of innovativeness, technological competencies and customer responsiveness would result to increased customer retention in the mobile services sector. Therefore, the research model argued that when customers perceived their mobile service providers to have the creativity, competencies and responsive minds to deliver satisfactory services (high value products/services) they tend to have high retention tendencies. Thus, a high quality service has the potential to impact on customer retention propensity. The model also affirmed that the association between SERVQUAL and retention is mediated by customer satisfaction. Hence, to achieve the study's designed objectives; we hypothesised based on the framework as follows:

$\mathrm{H}_{1}$. Service quality has no significant effect on consumer retention in the mobile services sector.

$\mathrm{H}_{2}$. There is no significant relationship amongst each of the dimensions of service quality and customer retention in the mobile services sector.

$\mathrm{H}_{3}$. Customer satisfaction significantly mediates the relationship between service quality and customer retention in the mobile services sector.

\section{Methodology}

The survey was conducted on a population of 510 undergraduate students of Business Administration Department in Ibrahim Badamasi Babangida (IBB) University, Lapai, Nigeria. Using stratified sampling the students were categorised into four levels. In conformity with Krejcie and Morgan (1970), 224 questionnaires were distributed, out of which only 203 questionnaires (90.6\%) were successfully retrieved and used for final analysis.

Measurement items used in the survey were adapted from previous studies. Each item was placed on a sevenpoint scale ranging from $1=$ strongly agree to $7=$ strongly disagree. For instance, innovativeness with four items (Simon \& Yaya, 2012; Malhotra \& Malhotra, 2013), technological competence seven items (Malhotra \& Malhotra, 2013; Jun \& Cai, 2001), customer responsiveness four items (Malhotra \& Malhotra, 2013; Jun \& Cai, 2001), customer satisfaction five items (Fen \& Lian, 2007; Ndubisi, Malhotra \& Wah, 2008), and retention five items (Almossawi, 2012; Aydin et al., 2005). For all items reliability and convergent validation were observed and found within the satisfactory threshold.

\section{Results}

\subsection{Respondents Profile}

Result of demographic information shows that out of 203 respondents, 139 (68.5\%) are male students while 64 (31.4\%) 
are female. Majority of the respondents $173(85.2 \%)$ are single while $30(14.8 \%)$ are married. Of these, $153(75.4 \%), 49$ (24.1\%) and 1 (0.5\%) are in between the age group of 15-25, 26-35 and 36-45 respectively. This gives an indication that the respondents are young and energetic. Exactly $171(84.2 \%)$, of the respondents had working experience of between 0 5 years; and $26(12.9 \%)$ had 5-10 years, $3(1.5 \%)$ had 10-20 years while $2(1 \%)$ had over 20 years working experience. This is also an indication that most undergraduate students in Nigerian universities are unemployed.

\subsection{Test of Reliability and Multicollinearity}

To ascertain the internal consistency of the measurement items used Cronbach's alpha a of acceptable minimum threshold of 0.7 as suggested by (Nunally, 1978; Nunnally \& Bernstein, 1994; Hair et al., 2010) is considered. The result of the reliability test shows that overall retention has 0.812 , innovation 0.673 , technological reliability 0.804 , responsiveness 0.736 and satisfaction 0.910 . Thus, indicates that Cronbach's a values is within the range of minimum acceptable threshold. Though innovation is nearly within the agreed value, there exists an acceptable minimum value of 0.6 (Hair, Anderson, Tatham, \& Black, 1998).

Convergent validity which is a measure of variable coefficient/correlation of factor loadings for each items namely innovativeness, technological competence, responsiveness, retention and satisfaction are between the range 0.938 to 0.537, which are all above the recommended value of 0.5 (Hair, Anderson, Tatham \& Black, 2005). Higher loadings indicate better correlation of the items in relation to their variables. To measure the degree of sampling adequacy of items for each variable Kaiser-Meyer-Olkin (KMO) index ranges between 0.858 to 0.719 indicating high sampling adequacy.

In detecting and diagnosing multicollinearity two major techniques are used: calculation of tolerance levels and variance inflation factor (VIF) values for each variable. Multicollinearity is defined as the strength of relationships exhibited among three or more independent or predictor variables in an equation (Sani \& Isaac, 2011). It represents the extent to which any predictor variable's effect can be predicted by any other predictor variables being analyzed (Hair et al., 2007). Thus, the possibility to establish and distinguish a particular variable's effect can be compromised as multicollinearity increases. As depicted in the table 1 below the tolerance levels for each variables ranges between 0.925 to 0.565 none is less than or equals to 0.02: and their variance inflation factor (VIF) values are well below 5 as suggested by Hair et al. (2011). Hence, items chosen to measure predictor variables indicate the existence of non multicollinearity.

\subsection{Test of Hypotheses}

From the study's framework, SERVQUAL comprised of three dimensions as used in previous studies. Overall, result indicates that customer retention is to a large extent influenced by mobile firms' service quality with an $R^{2}$ of 0.777 and adjusted $R^{2}$ of 0.597 . This further implies that about $77.7 \%$ of the variation in customer retention is explained by service quality dimensions and the mediating variables used in this survey.

Table 1: Results of Standardized Regression Model

\begin{tabular}{lccccc}
\hline Variables & STD Beta & t- values & Significant & Tolerance level & VIF \\
\hline Innovation & 0.189 & 3.197 & $0.002^{* *}$ & 0.661 & 1.513 \\
Technological competence & 0.269 & 4.142 & $0.000^{* * *}$ & 0.565 & 1.770 \\
Customer Responsiveness & 0.480 & 8.222 & $0.000^{* * *}$ & 0.690 & 1.449 \\
Customer Satisfaction & 0.233 & 3.111 & $0.002^{* *}$ & 0.925 & 1.081 \\
R & 0.777 & - & - & - & - \\
Adjusted R & & - & - & - & - \\
F-value & 0.597 & - & - & - & - \\
Durbin-Watson & 84.45 & - & $0.000^{* * *}$ & - & - \\
$* * *:$ P<0.001; **: P<0.01; & 2.121 & - & - & &
\end{tabular}

As further confirmed in table 1 above, innovativeness, technological competence and customer responsiveness have significant positive influence on consumer retention. This give a Beta values of $(\beta=0.189, p<0.01),(\beta=0.269, p<$ $0.001)$, and $(\beta=0.480, p<0.001)$ respectively. Based on the Std. beta values, customer responsiveness was found to have a larger effect on retention followed by organizational technological competence. Hence, alternate hypothesis one which stated that service quality of a mobile service provider significantly influenced their customers' retention is supported. 
Table 2: Correlation Analysis and Descriptive Statistics of Variables

\begin{tabular}{lccccccc}
\hline Variables & 1 & 2 & 3 & 4 & 5 & Mean & Std. Deviation \\
\hline 1. Innovation & 1.00 & 0.556 & 0.382 & 0.247 & $0.52^{* *}$ & 2.60 & 1.09 \\
2. Technological competence & - & 1.00 & 0.540 & 0.171 & $0.63^{* *}$ & 2.53 & 1.11 \\
3. Responsiveness & - & - & 1.00 & 0.204 & $0.69^{* *}$ & 2.34 & 1.01 \\
4. Satisfaction & - & - & - & 1.00 & 0.23 & 2.29 & 0.97 \\
5. Retention & - & - & - & - & 1.00 & 2.42 & 1.12 \\
\hline
\end{tabular}

The results in table 2, indicates that the three dimensions of service quality namely; innovativeness, technological competence and customer responsiveness are positively related with customer retention with correlation values of $(r=$ $0.52, p<0.01),(r=0.63, p<0.01)$ and $(r=0.69, p<0.01)$ respectively. However, customer responsiveness was found to have the greatest correlation $(r=0.69, p<0.01)$, suggesting that efficient implementation of SERVQUAL strategies and policies have the highest potential to influence customer retention in the mobile service sector, followed by technological competence and innovativeness i.e. reflecting the sincere commitment of top and middle level organizational managers to provide the necessary facilities that will create enabling atmosphere for the development of service employees. These results provide support for alternate hypothesis two that, there is significant relationship amongst each of the dimensions of service quality and customer retention in the mobile services sector.

\subsection{Mediation Test}

In testing the mediating hypothesis, the standardized beta coefficients for variables were observed where $a, b$ and $c$ represents the independent, mediating and dependent variables (Baron \& Kenny, 1986) respectively. As shown in table 3 below, the relationship between SERVQUAL dimensions i.e. innovativeness, technological competence, responsiveness and retention have higher coefficients of $0.189,0.269$ and 0.480 . While SERVQUAL dimensions and customer satisfaction has lower coefficients of $0.181,0.013$ and 0.127 respectively. This gives an indication of partial mediation because coefficient values with direct relationship are higher than with indirect relationship. Hence, customer satisfaction partially mediates the relationship between service quality and customer retention in the mobile services sector. Similar result is supported given a standardized beta coefficient of $0.233, p<0.01$ in table 1.

Table 3: Results of Standardized Coefficient of Variables

\begin{tabular}{|c|c|c|c|c|}
\hline Variables & a & $\rightarrow c$ (Std. Beta) & $\mathrm{a} \rightarrow \mathrm{b}$ (Std. Beta) & Decision \\
\hline Innovativeness & & 0.189 & 0.181 & \multirow{3}{*}{$\begin{array}{c}\text { Partial } \\
\text { Mediation }\end{array}$} \\
\hline Technological competence & & 0.269 & 0.013 & \\
\hline Customer responsiveness & & 0.480 & 0.127 & \\
\hline
\end{tabular}

\section{Discussion}

The findings of this study show that a vast majority of the respondents (i.e. students) are young energetic youths who are mostly unemployed, unmarried and between the age range of 15-20 years. Measurement instruments for constructs used in the study i.e. service quality, customer satisfaction and retention were all reliable and valid in line with appropriate statistical procedures.

To a large extent the results of this survey have confirmed that favourable SERVQUAL plan and implementation is a predictor to high customer retention tendency in the mobile services industry. The more effective a service provider' strategy in terms of quality services the greater the level of customer retention. Our model explains $59.7 \%$ of the variation in undergraduate students' retention of mobile services.

Customer responsiveness has the topmost standardized coefficient $(\beta=0.480)$. This implies that customer responsiveness provided more in explaining the influence of service quality on Nigerian undergraduate students' retention. It also suggests a moderate level of implementation of service quality strategies and policies by mobile service providers in Nigeria. Also, the fact that innovation had that least standardized coefficient $(\beta=0.189)$ implies that absence of improved and modernized products or services in the mobile service industry is constraining students retention propensity. 
Furthermore, to determine the intensity of agreement between the variables a mean score criteria was considered based on scores of 2.99 or less than that to be "Low", 3.00 to 4.99 as "Moderate" and 5.00 or higher than that as "High". The results revealed that innovation, technological competence and customer responsiveness have mean scores of 2.60, 2.53 and 2.29 considered low respectively. This suggests that students perceived the implementation of SERVQUAL strategies in the Nigeria's mobile services sector to be low. Hence, operators should design and implement appropriate quality service plans targeted at increased customer retention propensity. Our findings are in contrast with Malhotra and Malhotra (2013) who conducted a study on mobile services to both graduate and undergraduate students in the US. Their study found that innovation and technological competence have higher mean scores of 4.21 and 4.71 respectively. The differences could be due to the differences in the nature of states.

Overall our findings provide support for the three hypotheses except for customer satisfaction that revealed partial mediation relationship. Innovation, technological competence and customer responsiveness have a significant positive relationship with retention. This implies that greater level of students' retention of mobile services will be achieved if students perceived SERVQUAL standards to be effective. Standard services ensure that students are offered creative, customized and high value services capable of satisfying their changing wants and preferences.

\section{Conclusion}

It has become obvious that the survival of mobile service businesses requires understanding of the essential factors responsible for customer satisfaction. To succeed and compete for greater market share in the fiercely competitive mobile service sector Nigerian operators need to develop and implement appropriate service quality strategies that are capable of satisfying the expectations of students. This can be achieved by providing creative and customized services that concur with changing students' wants and preferences in order to encourage repeated purchase thereby shaping their retention propensity.

The findings provided evidence for the value added by SERVQUAL and its dimensions in shaping and enhancing students' retention propensity in the Nigerian mobile services industry. Innovativeness, technological competence and customer responsiveness were reported to have significant positive influence on students' retention, even though the impact of customer responsiveness was greater. Customer satisfaction of students' does partially mediate the relationship between service quality and students retention of mobile services. A wide gap exist in terms of service quality implementation level amongst developed and developing states like Nigeria as evident in a US study using same dimensions. The results have provided support for all hypotheses. Therefore this study has contributed greatly to literature through empirically based literature for the impact of service quality on students' retention in the Nigerian mobile services sector.

Some key limitations of this study were that the population comprises of only undergraduate students of Business Administration Department without considering other departments in the faculty visa vies other faculties in the University. Respondents sampled should have incorporated students at different levels in each department/faculty. Even though all undergraduate students' in Nigerian universities were believed to be consuming similar services offered by service operators. Future research is expected to broaden the sample and scope of this study and focus on classifying and perhaps examining other measures of customer satisfaction within the mobile service context. More so it is essential to develop better model that integrates other SERVQUAL dimensions outside the ones used in this research and to assess their impact.

\section{References}

Adeleke, A. and Aminu, S. A. (2012), "The determinants of customer loyalty in the Nigeria's GSM market", International Journal of Business and Social Science, Vol. 3, No. 14, pp. 209-222.

Ahn, J. H., Han, S. P. and Lee, Y. S. (2006), "Customer churn analysis: Churn determinants and mediation effects of partial defection in the Korean mobile telecommunications service industry", Telecommunications Policy, Vol. 30, No. 10, pp. 552-568.

Almossawi, M. M. (2012), "Consumers' true brand loyalty: the central role of commitment", Journal of Strategic Marketing, Vol. 6 No. 4, pp. 305-319.

Anderson, E.W. and Sullivan, M.W. (1993), "The antecedents and consequences of customer satisfaction for firms", Marketing Science, Vol. 12 No. 2, pp. 125-43.

Aydin, S., Ozer, G. and Arasil, O. (2005), "Customer loyalty and the effect of switching costs as a moderator variable: a case in the Turkish mobile phone market", Marketing Intelligence and Planning, Vol. 23 No. 1, pp. 89-103.

Baron, R. M. and Kenny, D. A. (1986), "The moderator-mediator variable distinction in psychological research: conceptual, strategic and statistical considerations", Journal of Personality and Psychology, Vol. 51, No. 6. pp. 1173-82. 
Carton, P. (2011), "New survey shows Verizon iPhone will have major impact on US wireless service providers: can AT\&T forestall large-scale defections?", available at www.investorplace.com/28029/impact-verizon-apple-iphonewireless-service- providers/ (accessed January 31, 2011).

Caruana, A. and Malta, M. (2002), "The effects of service quality and the mediating role of customer satisfaction", European Journal of Marketing vol. 36 No. 7/8, 2002 pp. 811- 828.

Choi, C., Kim, C., Sung, N. and Park, Y. (2007), "Evaluating the quality of service in mobile business based on fuzzy set theory", Fourth International Conference on Fuzzy Systems and Knowledge Discovery, Haiku, China, August 2007, pp. 483-7.

Clark, M. (1997), "Modelling the impact of customer-employee relationships on customer retention rates in a major UK retail bank", Management Decision, Vol. 35 Iss: 4 pp. $293-301$.

Coussement, K., Benoit, D. F. and van den Poel, D. (2010), Improved marketing decision making in a customer churn prediction context using generalized additive models. Expert Systems with Applications, Vol. 37, No. 3, pp. 2132-2143.

Cronbach, L. J. (1951), "Coefficient alpha and the internal structure of test", Psychomerika Vol. 16. No. 3, pp. 297-333.

Fen, Y. S. and Lian, K. M. (2007), "Service quality and customer satisfaction: Antecedents of customer's repatronage intentions", Sunway Academic Journal, Vol. 4, 59-73.

Fornell, C. (1992), "A national customer satisfaction barometer", Journal of Marketing, Vol. 56 No. 1, pp. 6-21.

Gan, C., Cohen, D., Clemes, M. and Chong, E. (2006), "A survey of customer retention in the New Zealand banking industry: Banks and Bank Systems,Vol 1(4), pp. 83-99.

Gera, R. (2011), "Modelling e-service quality and its consequences in India: an SEM approach",Journal of Research in Interactive Marketing Vol. 5 No. 2/3, 2011 pp. 203- 225.

Gerpott, T.J., Rams, W. and Schindler, A. (2001), "Customer retention, loyalty and satisfaction in the German mobile cellular telecommunications market", Telecommunications Policy, Vol. 25 No. 4, pp. 249-69.

Glady, N., Baesens, B. and Croux, C. (2009), Modeling churn using customer lifetime value. European Journal of Operational Research, 197, 1, pp. 402-411.

Hair, J., Black, W. C., Babin, B. J., and Anderson, R. E. 2010, "Multivariate Data Analysis. 7th ed. Upper saddle River", New Jersey: Pearson Education International.

Hair, J.F. Jr, Anderson, R.E., Tatham, R.L. and Black, W.C. (1998), "Multivariate Data Analysis", 5th ed., Prentice-Hall, New York, NY.

Hair, J.F. Jr, Black, W.C., Babin, B., Anderson, R. and Tatham, R. (2007), "Multivariate Data Analysis", 6th ed., Prentice-Hall, New Jersey, NJ.

Hair, J. F., Ringle, C. M. and Sarstedt, M. (2011), "PLS-SEM: Indeed a Silver Bullet. Journal of Marketing Theory and Practice, 18, 139152.

Hamblen, M. (2010), "Subscribers more satisfied with cell phone carriers: Sprint jumps $11 \%$ in customer satisfaction survey", available at: www.computerworld.com/s/article/.

Hutcheson, G.D. and Moutinho, L. (1998), "Measuring preferred store satisfaction using consumer choice criteria as a mediating factor", Journal of Marketing Management, Vol. 14 No. 7, pp. 705-20.

Jaiswal, A.K. (2008), "Customer satisfaction and service quality measurement in Indian call centres", Managing Service Quality Vol. 18 No. 4, 2008 pp. 405-416.

Johnson, W.C. and Sirikit, A. (2002), "Service quality in the Thai telecommunication industry: a tool for achieving a sustainable competitive advantage", Management Decision, Vol. 40 Iss: 7 pp. 693 - 701.

Jun, M. and Cai, S. (2001), "The key determinants of Internet banking service quality: a content analysis", International Journal of Bank Marketing, Vol. 19 Iss 7 pp. $276-291$.

Kim, M.K., Park, M.C. and Jeong, D.H. (2004), "The effects of customer satisfaction and switching barrier on customer loyalty in Korean mobile telecommunication services", Telecommunications Policy, Vol. 28 No. 2, pp. 145-59.

Kotler, P. (2003), Marketing Management, Prentice-Hall, Englewood Cliffs, NJ.

Krejcie, R. V. and Morgan, D. W. (1970), "Determining sample size for research activities, Educ Psychol Meas.

Lim, H., Widdows, R. and Park, J. (2006), "M-loyalty: winning strategies for mobile carriers", Journal of Consumer Marketing, Vol. 23 No. 4, pp. 208-18.

Malhotra, A. and Malhotra, C. K. (2013), "Exploring switching behavior of US mobile service customers", Journal of Services Marketing $27 / 1$ (2013) 13-24.

Martin, S. S. and Catalán, B. L. (2013),"How can a mobile vendor get satisfied customers?", Industrial Management \& Data Systems, Vol. 113 Iss 2 pp. $156-170$.

Ndubisi, N. O., Malhotra, N. K., and Wah, C. K. (2008), "Relationship marketing, customer satisfaction and loyalty: a theoretical and empirical analysis from an Asian perspective", Journal of International Consumer Marketing, 21(1), 5-16.

Nunally, J. C. (1978), "Psychometric Theory, $2^{\text {nd }}$ edition, McGraw Hill, NewYork, NY.

Nunally, J. C. and Bernstein, I. H. (1994), "Psychometric theory, New York: McGraw-Hill.

OECD (2005), The Measurement of Scientific and Technological Activities: Oslo Manual Guidelines for Collecting and Interpreting Innovation Data, 3rd ed., OECD Eurostat, Paris.

Omar, N. A. and Musa, R. (2011), "Measuring service quality in retail loyalty programmes (LPSQual) Implications for retailers' retention strategies", International Journal of Retail \& Distribution Management Vol. 39 No. 10, 2011 pp. 759-784.

Omotayo, O. and Joachim, A.A. (2008), "Customer service in the retention of mobile phone users in Nigeria", African Journal of Business Management Vol.2 (2), pp. 026 -031. 
Parasuraman, A., Zeithaml, V. A. and Berry, L. L. (1985), "A conceptual model of service quality and its implication for future research", Journal of Marketing, Vol. 49, April, pp. 41-50.

Parasuraman, A., Zeithaml, V. A. and Berry, L. L. (1988), "SERVQUAL: a multiple item scale for measuring consumer perceptions of service quality", Journal of Retailing, Vol. 64, No. 1, Spring, pp. 12-40.

Peng, J., Quan, J. and Zhang, S. (2013), "Mobile phone customer retention strategies and Chinese e-commerce: Electronic Commerce Research and Applications", Vol. 12 No. 5, pp. 1-7.

Poon, W. C. and Low, K. L. T. (2005),"Are travellers satisfied with Malaysian hotels?", International Journal of Contemporary Hospitality Management, Vol. 17 Iss 3 pp. 217 - 227.

Rahman, S. and Azhar, S. (2011), "Xpressions of generation Y: perceptions of the mobile phone service industry in Pakistan", Asia Pacific Journal of Marketing and Logistics, Vol. 23 No. 1, pp. 91-107.

Reichheld, F.F. and Sasser, W.E. Jr (1990), "Zero defections: quality comes to services", Harvard Business Review, Vol. 68, pp. 105-11.

Rust, R. T. And Zahorik, A. J. (1993), "Customer satisfaction, customer retention, and market share, Journal of Retailing, Vol. 69 No. 2 , pp. 193-215.

Sani, A. D. and Isaac, A. S. (2011), "Human resource development climate and employee engagement in the public sector: an empirical examination", lapai Journal of Management Science, Vol. 2, Nos. 1 \& 2, pp. 108-120.

Santos, J. (2003), "E-service quality: a model of virtual service quality dimensions", Managing Service Quality, Vol. 13 No. 3, pp. $233-46$.

Santouridis, I. and Trivellas, P. (2010), "Investigating the impact of service quality and customer satisfaction on customer loyalty in mobile telephony in Greece", The TQM Journal Vol. 22 No. 3, 2010 pp. 330-343.

Seo, D., Ranganathan, C., and Babad, Y. (2008), Two-levelmodel of customer retention in the US mobile telecommunications service market. Telecommunications Policy, Vol. 32, No. 3, pp. 182-196.

Shin, D. and Kim, W. (2008), "Forecasting customer switching intention in mobile service: an exploratory study of predictive factors in mobile number portability", Technological Forecasting \& Social Change, Vol. 75 No. 6, pp. 854-87.

Simon, A. and Yaya, L. H.P. (2012),"Improving innovation and customer satisfaction through systems integration", Industrial Management \& Data Systems, Vol. 112 Iss 7 pp. 1026 - 1043.

Stark, J. (2011), "Product lifecycle management", available at: www.johnstark.com/ （accessed 3 November 2011). 